\title{
Determination of the Aquifer System of the Northern Sector of Bida Basin, Nigeria Using Electrical Resistivity Method
}

\author{
A. Idris-Nda ${ }^{1}$, M. I. Ogunbajo ${ }^{2} \&$ P. I. Olasehinde ${ }^{3}$ \\ ${ }^{1}$ Department of Geology, Federal University of Technology, Minna, Nigeria \\ Correspondence: A. Idris-Nda, Department of Geology, Federal University of Technology, Minna, Nigeria. Tel: \\ 234-803-627-3815. E-mail: idrisnda@futminna.edu.ng
}

Received: January 15, 2013

Accepted: February 16, 2013 Online Published: March 28, 2013

doi:10.5539/jgg.v5n2p18

URL: http://dx.doi.org/10.5539/jgg.v5n2p18

\begin{abstract}
The northern sector of the Bida Basin extends from Gulu in the south to Kontagora in the north, where it contacts the crystalline rock of the Basement Complex system. It lies between latitudes $5^{\circ} 80^{\prime}$ and $10^{\circ} 50^{\prime} \mathrm{N}$ and longitudes $4^{\circ} 50^{\prime}$ and $7^{\circ} 00^{\prime} \mathrm{E}$. The Basin consists of Maastrichtian sedimentary deposits comprising of the Bida Sandstone, Sakpe Ironstone, Enagi Siltstone and Batati Ironstone Formations, with a total sedimentary pile of between 3500 to $4500 \mathrm{~m}$. The aquifer is composed mainly of coarse to medium grained sandstone. Geoelectric survey was conducted using the Schlumberger configuration to a total AB/2 separation of $300 \mathrm{~m}$. 140 Vertical Electrical Sounding (VES) points were established along nine profiles spread across the Basin. The resulting curves were interpreted both qualitatively and quantitatively using visual inspection of the field curve, curve fitting using standard master and subsidiary curves as well as by computer iteration (Interpex IX1D). The results indicate that the dominant curve types are the AA, QQH and KQ. Four groups of curve types were obtained in the Basin, Group 1 (H, K), Group 2 (A, AA, KHK), Group 3 (HK, HKQ, KHKQ, KHKHK, QQH) and Group 4 (QHK, KQQ, KQ, QHK, Q). Based on these four groups the Basin was divided into a northern, central and southern sectors as well as geological contact areas. Geoelectric sections, developed from geoelectric logs show that three types of aquifers exist at various depths; a perched aquifer with a depth of between 5 to $20 \mathrm{~m}$, a semi confined / confined aquifer at between 30 to $60 \mathrm{~m}$ and an unconfined aquifer with undetermined thickness. The topsoil has a resistivity range of 50-500 Ohm-meters, ferruginised sandstone, 800-2000 Ohm-meters, sandy clay, 150-500 Ohm-meters, sandstone 300-1500 Ohm-meters and clay/shale, 10 to $100 \mathrm{Ohm}$-meters. The aquifer is represented by the sandstone.
\end{abstract}

Keywords: Bida Basin, resistivity, aquifer, curve type

\section{Introduction}

The Mid-Niger Basin otherwise known as the Bida Basin or the Nupe Basin is a NW-SE trending intracratonic sedimentary basin extending from Kontagora in Niger State of Nigeria to areas slightly beyond Lokoja in the south. It is delimited in the northeast and southwest by the basement complex while it merges with Anambra and Sokoto basins in sedimentary fill comprising post orogenic molasse facies and a few thin unfolded marine sediments (Adeleye, 1974). The basin is a gently downwarped trough whose genesis may be closely connected with the Santonian orogenic movements of southeastern Nigeria and the Benue valley, nearby. The basin is a NW-SE trending embayment, perpendicular to the main axis of the Benue Trough and the Niger Delta Basin (Figure 1). It is frequently regarded as the northwestern extension of the Anambra Basin, both of which were major depocentres during the third major transgressive cycle of southern Nigeria in Late Cretaceous times (Obaje, 2009). Interpretations of Landsat images, borehole logs, as well as geophysical data across the entire Bida Basin suggest that the basin is bounded by a system of linear faults trending NW-SE (Kogbe et al., 1983). Gravity studies also confirm central positive anomalies flanked by negative anomalies as shown for the adjacent Benue Trough and typical of rift structures (Ojo, 1984; Ojo \& Ajakaiye, 1989). The area of study is the northern sector of the Basin which extends from Gulu area in the south to Kontagora/Auna in the north (both in Niger state) where it contacts the crystalline rocks of the Basement Complex system. It lies between latitude $8^{\circ} 50^{\prime} \mathrm{N}$ and $10^{\circ} 50^{\prime} \mathrm{N}$ and longitude $4^{\circ} 50^{\prime} \mathrm{E}$ and $7^{\circ} 00^{\prime} \mathrm{E}$ covering an area of about $300 \mathrm{~km}^{2}$ north of River Niger. 


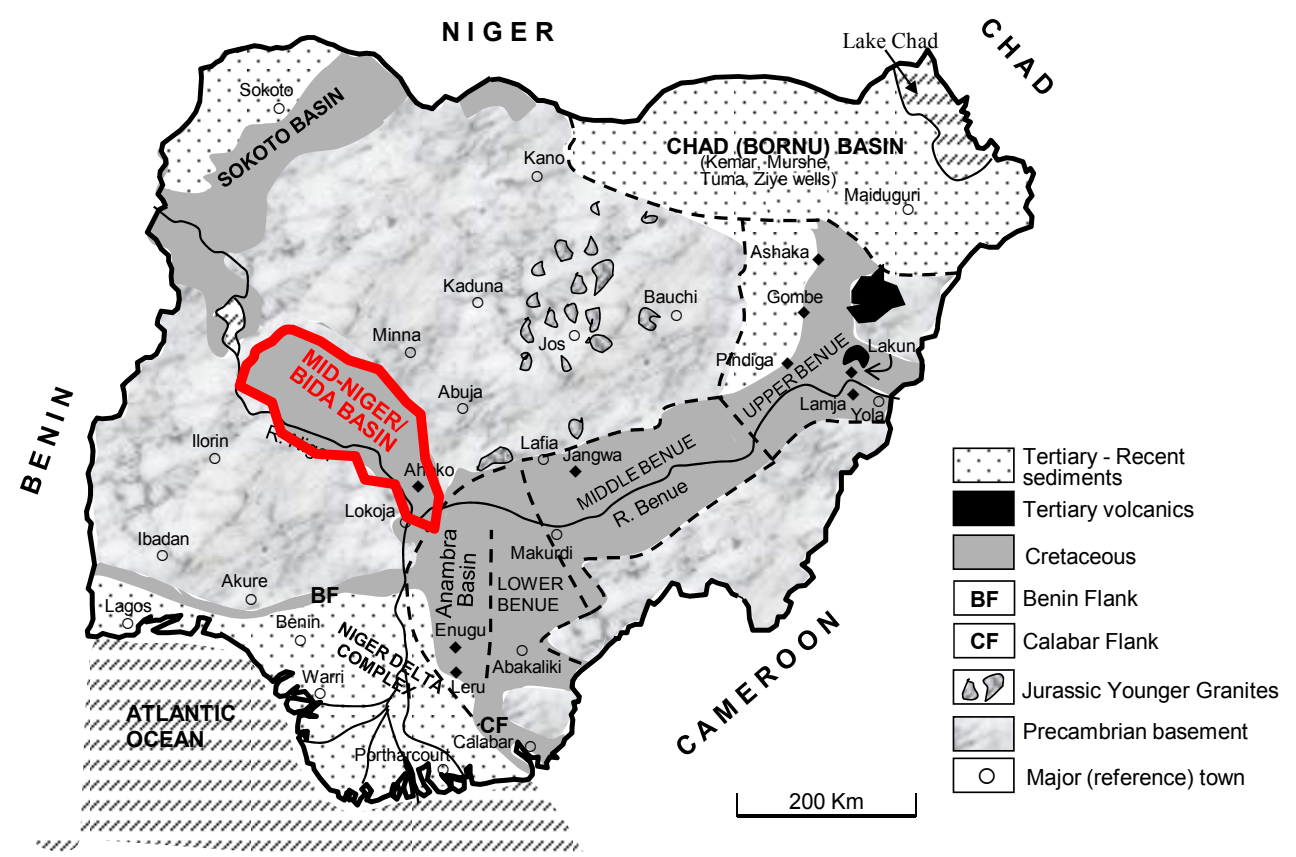

Figure 1. Sketch geological map of Nigeria showing the location of the Bida Basin (modified after Obaje, 2009)

\section{Geology}

The thickness of the sedimentary pile has been variously put at, $1.0 \mathrm{~km}$ (Whiteman, 1982) using aeromagnetic observations; $3.5 \mathrm{~km}$ (Ojo \& Ajakaiye 1976) using gravity measurements, Adeniyi $(1985,1986)$ also suggested $3.5 \mathrm{~km}$ using gravity measurements, while Udensi (2005) suggested an average thickness of $3.39 \mathrm{~km}$ using statistical spectral analysis of the residual total magnetic field, though two of the areas studied showed a thickness in excess of $4.50 \mathrm{~km}$. The oldest rocks exposed in the Bida basin are Maastrichtian in age but sedimentation may have started earlier. The rocks outcropping have been variously called the Nupe series, Nupe-sandstone series (Falconer, 1911; Geological survey of Nigeria, 1956). Jacques (1945) divided the Bida Basin sandstone into Nupe sandstone and the Nupe Basal conglomerate. The Geological survey of Nigeria (1956) assigned a Senonian age to the rocks. The Basin is poor in fossils and the age of the formation has been determined mainly by photogeological correlation with the post-Santonian sequence of the Anambra Basin (Dessauvagie, 1972). The stratigraphy and sedimentation of the Bida Basin have been studied in detail by Adeleye (1972) and Adeleye and Dessauvagie (1972).

Table 1. Stratigraphic section of the Bida Basin (Adeleye, 1972)

\begin{tabular}{|c|c|c|c|c|}
\hline Age & Southern Basin & \multicolumn{3}{|c|}{ Northern Basin } \\
\hline Post Cretaceous & Laterite, alluvium & Later & te, alluvium & \\
\hline \multirow{7}{*}{ Upper Cretaceous } & & \multirow{7}{*}{ 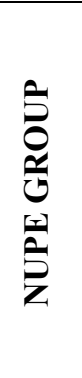 } & & Edozhigi member \\
\hline & Agbaja Formation & & Batati ironstone Formation & Kutigi member \\
\hline & Patti Formation & & Enagi siltstone Formation & \\
\hline & \multirow{4}{*}{ Lokoja Formation } & & \multirow{2}{*}{ Sakpe ironstone } & Wuya member \\
\hline & & & & Baro member \\
\hline & & & \multirow{2}{*}{ Bida Sandstone Formation } & Jima member \\
\hline & & & & Doko member \\
\hline Pre Cambrian & Basement complex & & & \\
\hline
\end{tabular}




\section{Methodology}

Geophysical survey was conducted in the area using the Electrical Resistivity method. The subsurface data of interest in this study using surface geophysical surveys include the determination of the following;

i. Detection of the position, extent and volume of potential aquifers,

ii. Estimation of the thickness of the various geological units,

iii. Determining discontinuity in extent of the aquifers,

iv. Detection of aquitards and connections between different aquifers,

v. Establishing lateral and vertical variations in lithology with distance and depth,

vi. Determining resistivity range for the materials that make up the Basin.

These parameters were determined using the Electrical Resistivity method of survey, electrode configurations deployed for the study were the Schlumberger and modified Schlumberger arrays.

Over 300 Vertical Electrical Soundings (VES) were conducted across the Basin out of which 140 were done along nine profile lines covering the Basin (Figure 2), an attempt was made for the profiles to cover the entire study area, with between seven to twelve soundings along each profile. The equipment used for the study was the Geotron Resistivity meter model G41. Survey points were established using a Garmin Global Positioning System (GPS) Etrex Legend. Results of the geophysical surveys are shown in Table 2 and the curves are shown in Figure 4a and $5 \mathrm{a}$.

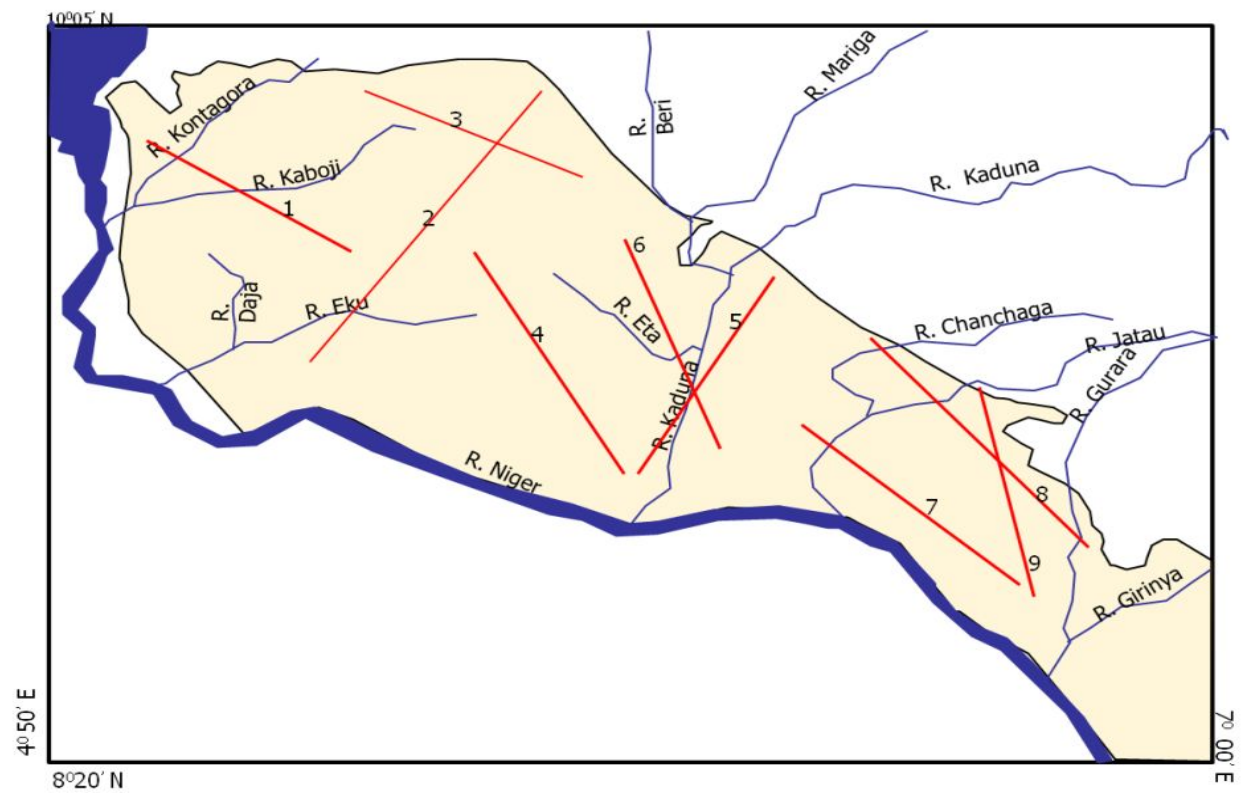

Figure 2. Profiles along which geophysical investigations were carried out

\section{Results and Interpretation}

\subsection{Results}

The Vertical Electrical Sounding (VES) curves were interpreted both qualitatively and quantitatively. The qualitative interpretation involved curve inspection, while the quantitative interpretation involved partial/complete curve matching with standard master and subsidiary curves, and also by field curve layering. The quantitative interpretation results were refined by computer iteration technique using the computer program Interpex IX1D.

The resulting geoelectric logs were correlated to establish the geoelectric sections which were used to characterize the aquifer types in the area. The lithologic logs obtained from boreholes in the area were correlated with the VES interpretations results, Figure 3. The correlation in depth between the VES results and lithological logs is, in most cases, better than 80 percent.

The interpreted curves were joined to bring out the geoelectric logs, geoelectrical sections were then drawn from 
the logs. The aquifer geometry in the area was determined using this method. Characteristic resistivity values were also determined for the various geological materials that make up the Basin. Figure4 shows a typical interpretation of the VES curve in a part of the Basin using the Interpex IX1D.

Table 2. Results of geoelectric surveys in the Bida Basin

\begin{tabular}{|c|c|c|c|c|c|c|c|c|c|c|c|c|c|}
\hline \multirow{3}{*}{ No } & \multirow{3}{*}{$\mathrm{AB} / 2$} & \multirow{3}{*}{$\mathrm{MN} / 2$} & \multirow{3}{*}{ K } & \multicolumn{10}{|c|}{ RESISTIVITY (Ohm-meter) } \\
\hline & & & & Muye & Kpada & Pati Ndaloke & Lokogoma & Tungan Kawo & Manigi & Bida & Makera & Salka & Matane \\
\hline & & & & $8.25 \mathrm{~N} 6.72 \mathrm{E}$ & $8.63 \mathrm{~N} 6.67$ & $9.15 \mathrm{~N} 6.26 \mathrm{E}$ & $9.34 \mathrm{~N} 6.03$ & $10.49 \mathrm{~N} 5.08 \mathrm{E}$ & $9.75 \mathrm{~N} 5.51 \mathrm{~F}$ & $9.07 \mathrm{~N} 5.99 \mathrm{E}$ & $9.68 \mathrm{~N} 5.40 \mathrm{E}$ & $10.18 \mathrm{~N} 4.58$ & $8110.01 \mathrm{~N} 5.38 \mathrm{~F}$ \\
\hline 1 & 1 & 0.5 & 2.36 & 137 & 1011 & 258 & 107 & 128 & 321 & 1450 & 83 & 90 & 349 \\
\hline 2 & 2 & 0.5 & 11.8 & 238 & 966 & 324 & 135 & 140 & 469 & 1359 & 121 & 51 & 283 \\
\hline 3 & 3 & 0.5 & 27.5 & 263 & 1040 & 114 & 378 & 127 & 516 & 1124 & 151 & 42 & 283 \\
\hline 4 & 5 & 0.5 & 77.8 & 257 & 1600 & 83 & 107 & 100 & 609 & 1053 & 227 & 40 & 330 \\
\hline 5 & 6 & 0.5 & 112 & 210 & 1694 & 76 & 105 & 152 & 1378 & 967 & 260 & 43 & 327 \\
\hline 6 & 6 & 1 & 55 & 220 & 1462 & 67 & 118 & 137 & 378 & 1133 & 241 & 38 & 319 \\
\hline 7 & 8 & 1 & 99 & 161 & 1305 & 66 & 136 & 148 & 480 & 1012 & 274 & 47 & 287 \\
\hline 8 & 10 & 1 & 156 & 120 & 1097 & 64 & 147 & 150 & 708 & 1069 & 308 & 59 & 273 \\
\hline 9 & 10 & 2.5 & 58.9 & 121 & 1187 & 66 & 132 & 81 & 741 & 1273 & 262 & 65 & 281 \\
\hline 10 & 15 & 2.5 & 137 & 54 & 800 & 54 & 177 & 177 & 860 & 1134 & 362 & 93 & 277 \\
\hline 11 & 20 & 2.5 & 247 & 25 & 485 & 46 & 219 & 147 & 1008 & 810 & 481 & 110 & 292 \\
\hline 12 & 30 & 2.5 & 562 & 19 & 415 & 35 & 245 & 113 & 1382 & 928 & 627 & 101 & 348 \\
\hline 13 & 40 & 2.5 & 1001 & 17 & 459 & 29 & 239 & 100 & 1577 & 869 & 685 & 96 & 363 \\
\hline 14 & 40 & 7.5 & 323 & 18 & 564 & 37 & 206 & 97 & 888 & 807 & 676 & 98 & 325 \\
\hline 15 & 50 & 7.5 & 512 & 14 & 694 & 32 & 108 & 83 & 963 & 788 & 748 & 93 & 338 \\
\hline 16 & 60 & 7.5 & 742 & 13 & 776 & 28 & 141 & 75 & 994 & 518 & 818 & 82 & 393 \\
\hline 17 & 70 & 7.5 & 1014 & 12 & 847 & 26 & 118 & 67 & 1149 & 445 & 820 & 70 & 473 \\
\hline 18 & 80 & 7.5 & 1329 & 13 & 903 & 21 & 98 & 60 & 1147 & 392 & 851 & 75 & 529 \\
\hline 19 & 80 & 15 & 647 & 30 & 1067 & 24 & 102 & 66 & 1124 & 411 & 904 & 82 & 445 \\
\hline 20 & 90 & 15 & 825 & 13 & 1096 & 18 & 78 & 48 & 1098 & 350 & 918 & 89 & 580 \\
\hline 21 & 100 & 15 & 1024 & 13 & 1256 & 14 & 69 & 46 & 1001 & 322 & 948 & 86 & 566 \\
\hline 22 & 110 & 15 & 1244 & 18 & 1508 & 18 & 64 & 44 & 946 & 308 & 1002 & 94 & 490 \\
\hline 23 & 120 & 15 & 1488 & 29 & 1921 & 22 & 62 & 42 & 883 & 292 & 1040 & 102 & 452 \\
\hline 24 & 130 & 15 & 1746 & 41 & 2124 & 30 & 66 & 38 & 767 & 286 & 1079 & 114 & 466 \\
\hline 25 & 130 & 30 & 1234 & 43 & 2167 & 51 & 68 & 40 & 669 & 297 & 1182 & 121 & 551 \\
\hline 26 & 140 & 30 & 2384 & 67 & 2218 & 77 & 72 & 36 & 520 & 277 & 1191 & 126 & 601 \\
\hline 27 & 150 & 30 & 2748 & 88 & 2230 & 91 & 29 & 33 & 499 & 281 & 1221 & 148 & 742 \\
\hline
\end{tabular}

\begin{tabular}{|c|c|c|c|c|c|c|c|c|c|c|c|c|c|}
\hline \multirow{3}{*}{ No } & \multirow{3}{*}{$A B / 2$} & \multirow{3}{*}{$\mathrm{MN} / 2$} & \multirow{3}{*}{$\mathrm{K}$} & \multicolumn{10}{|c|}{ RESISTIVITY (Ohm-meter) } \\
\hline & & & & FGGC Bida & Wuya Kede & Katcha & Salka & Gurai Kawo & Daja-Najata & Bwaje & Mokwa & Kutigi & Lapai \\
\hline & & & & $9.07 \mathrm{~N} 6.01 \mathrm{E}$ & $9.09 \mathrm{~N} 6.02 \mathrm{E}$ & $8.76 \mathrm{~N} 6.31 \mathrm{E}$ & $10.18 \mathrm{~N} 4.58 \mathrm{E}$ & $10.14 \mathrm{~N} 4.54 \mathrm{E}$ & $9.58 \mathrm{~N} 4.75 \mathrm{E}$ & $8.42 \mathrm{~N} 6.73 \mathrm{E}$ & $9.19 \mathrm{~N} 5.09 \mathrm{E}$ & $9.18 \mathrm{~N} 5.59 \mathrm{E}$ & $8.25 \mathrm{~N} 6.72 \mathrm{E}$ \\
\hline 1 & 1 & 0.5 & 2.36 & 1041 & 146 & 122 & 294 & 82 & 382 & 857 & 1051 & 298 & 137 \\
\hline 2 & 2 & 0.5 & 11.8 & 356 & 138 & 103 & 281 & 97 & 328 & 1203 & 608 & 399 & 238 \\
\hline 3 & 3 & 0.5 & 27.5 & 353 & 114 & 82 & 285 & 103 & 337 & 1300 & 522 & 450 & 263 \\
\hline 4 & 5 & 0.5 & 77.8 & 362 & 82 & 48 & 1047 & 212 & 343 & 1727 & 538 & 574 & 257 \\
\hline 5 & 6 & 0.5 & 112 & 367 & 69 & 34 & 1215 & 119 & 339 & 1873 & 381 & 601 & 210 \\
\hline 6 & 6 & 1 & 55 & 313 & 67 & 35 & 470 & 114 & 298 & 1690 & 334 & 564 & 220 \\
\hline 7 & 8 & 1 & 99 & 261 & 59 & 27 & 932 & 111 & 294 & 1905 & 266 & 573 & 161 \\
\hline 8 & 10 & 1 & 156 & 239 & 55 & 23 & 1884 & 114 & 280 & 2145 & 225 & 596 & 120 \\
\hline 9 & 10 & 2.5 & 58.9 & 243 & 60 & 24 & 69 & 126 & 273 & 2353 & 274 & 597 & 121 \\
\hline 10 & 15 & 2.5 & 137 & 237 & 56 & 18 & 92 & 130 & 233 & 2029 & 314 & 560 & 54 \\
\hline 11 & 20 & 2.5 & 247 & 233 & 50 & 16 & 177 & 151 & 235 & 3417 & 454 & 520 & 25 \\
\hline 12 & 30 & 2.5 & 562 & 200 & 46 & 15 & 1046 & 201 & 280 & 1224 & 379 & 558 & 19 \\
\hline 13 & 40 & 2.5 & 1001 & 153 & 53 & 15 & 1152 & 261 & 285 & 795 & 993 & 855 & 17 \\
\hline 14 & 40 & 7.5 & 323 & 125 & 78 & 20 & 407 & 252 & 269 & 2242 & 1202 & 798 & 18 \\
\hline 15 & 50 & 7.5 & 512 & 113 & 56 & 17 & 555 & 316 & 267 & 560 & 1054 & 812 & 14 \\
\hline 16 & 60 & 7.5 & 742 & 108 & 58 & 15 & 493 & 353 & 260 & 350 & 1517 & 791 & 13 \\
\hline 17 & 70 & 7.5 & 1014 & 102 & 60 & 14 & 415 & 404 & 268 & 218 & 1478 & 695 & 12 \\
\hline 18 & 80 & 7.5 & 1329 & 85 & 62 & 15 & 382 & 462 & 275 & 130 & 1822 & 577 & 13 \\
\hline 19 & 80 & 15 & 647 & 87 & 64 & 16 & 336 & 504 & 285 & 254 & 1411 & 747 & 16 \\
\hline 20 & 90 & 15 & 825 & 59 & 73 & 17 & 297 & 553 & 302 & 63 & 1332 & 726 & 13 \\
\hline 21 & 100 & 15 & 1024 & 61 & 79 & 20 & 236 & 586 & 361 & 45 & 1290 & 776 & 13 \\
\hline 22 & 110 & 15 & 1244 & 58 & 81 & 28 & 198 & 600 & 386 & 42 & 1306 & 820 & 13 \\
\hline 23 & 120 & 15 & 1488 & 54 & 72 & 33 & 164 & 634 & 390 & 51 & 1372 & 887 & 16 \\
\hline 24 & 130 & 15 & 1746 & 53 & 63 & 36 & 133 & 677 & 398 & 62 & 1383 & 937 & 22 \\
\hline 25 & 130 & 30 & 1234 & 50 & 60 & 42 & 137 & 691 & 401 & 78 & 1387 & 961 & 28 \\
\hline 26 & 140 & 30 & 2384 & 47 & 61 & 49 & 145 & 708 & 420 & 91 & 1148 & 994 & 37 \\
\hline 27 & 150 & 30 & 2748 & 48 & 58 & 57 & 157 & 717 & 443 & 102 & 1150 & 1102 & 46 \\
\hline
\end{tabular}



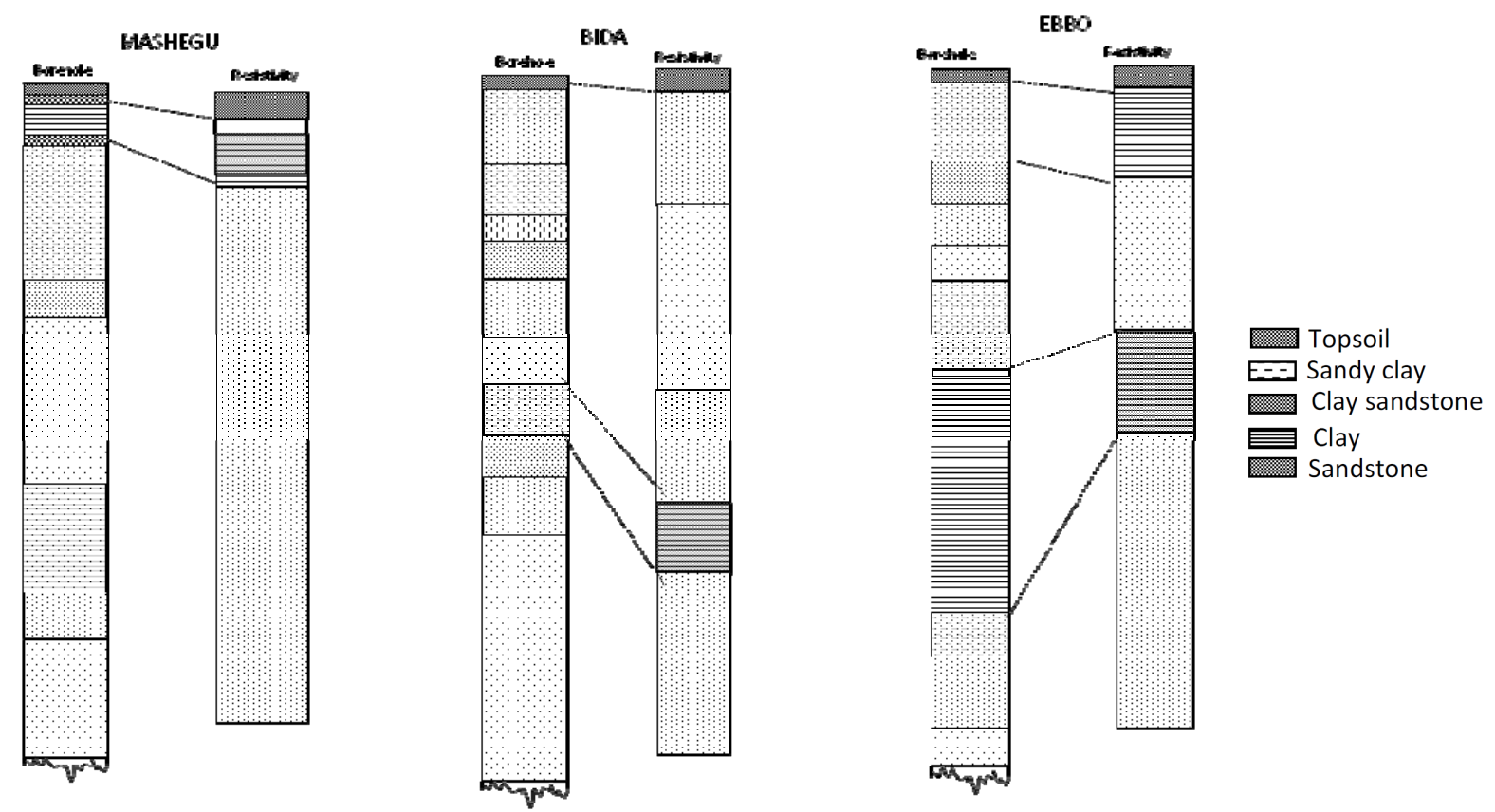

Figure 3. Correlation of VES data with borehole lithological logs
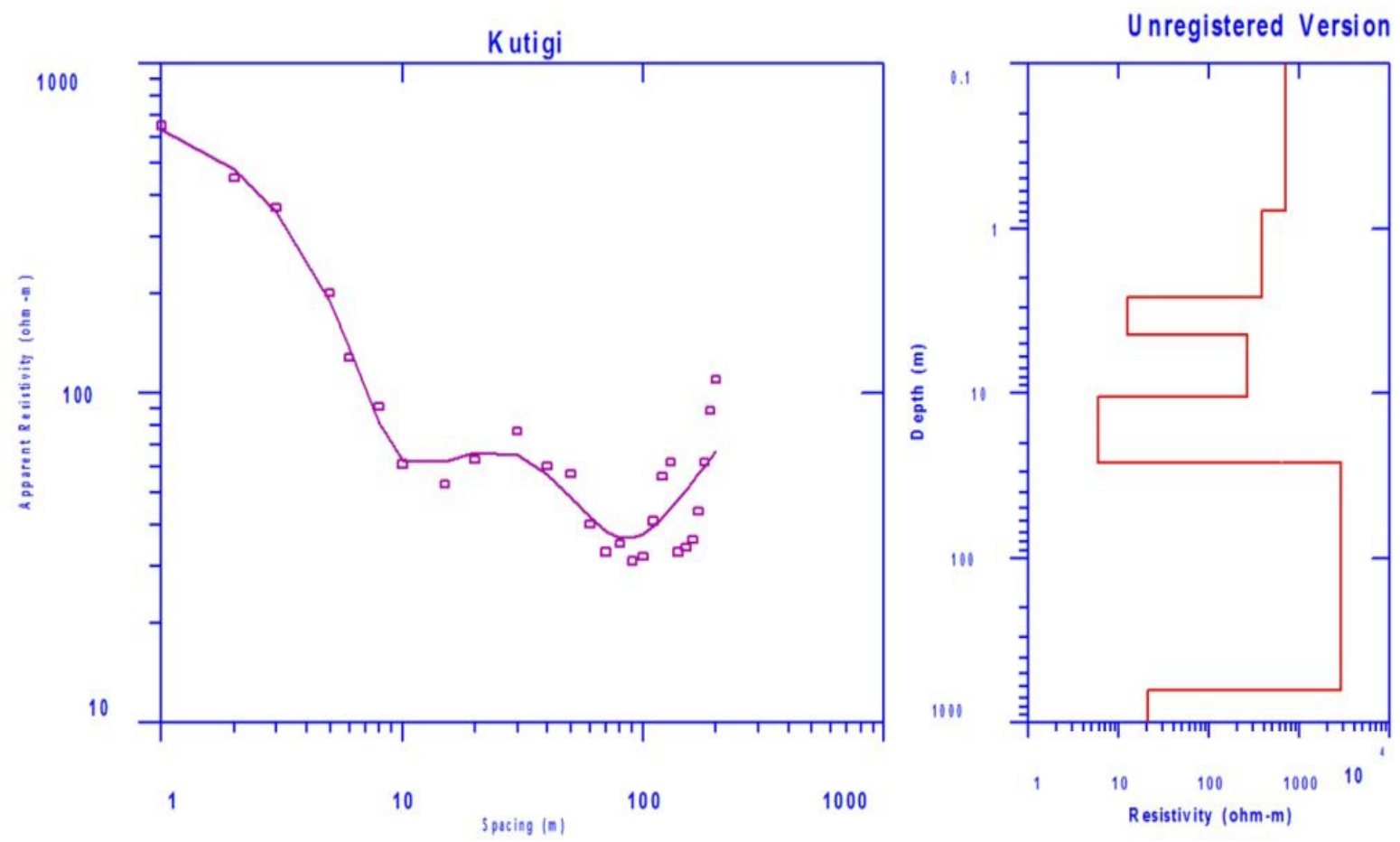

Figure 4. Interpreted VES curve for Kutigi in the Bida Basin 


\subsection{Interpretation}

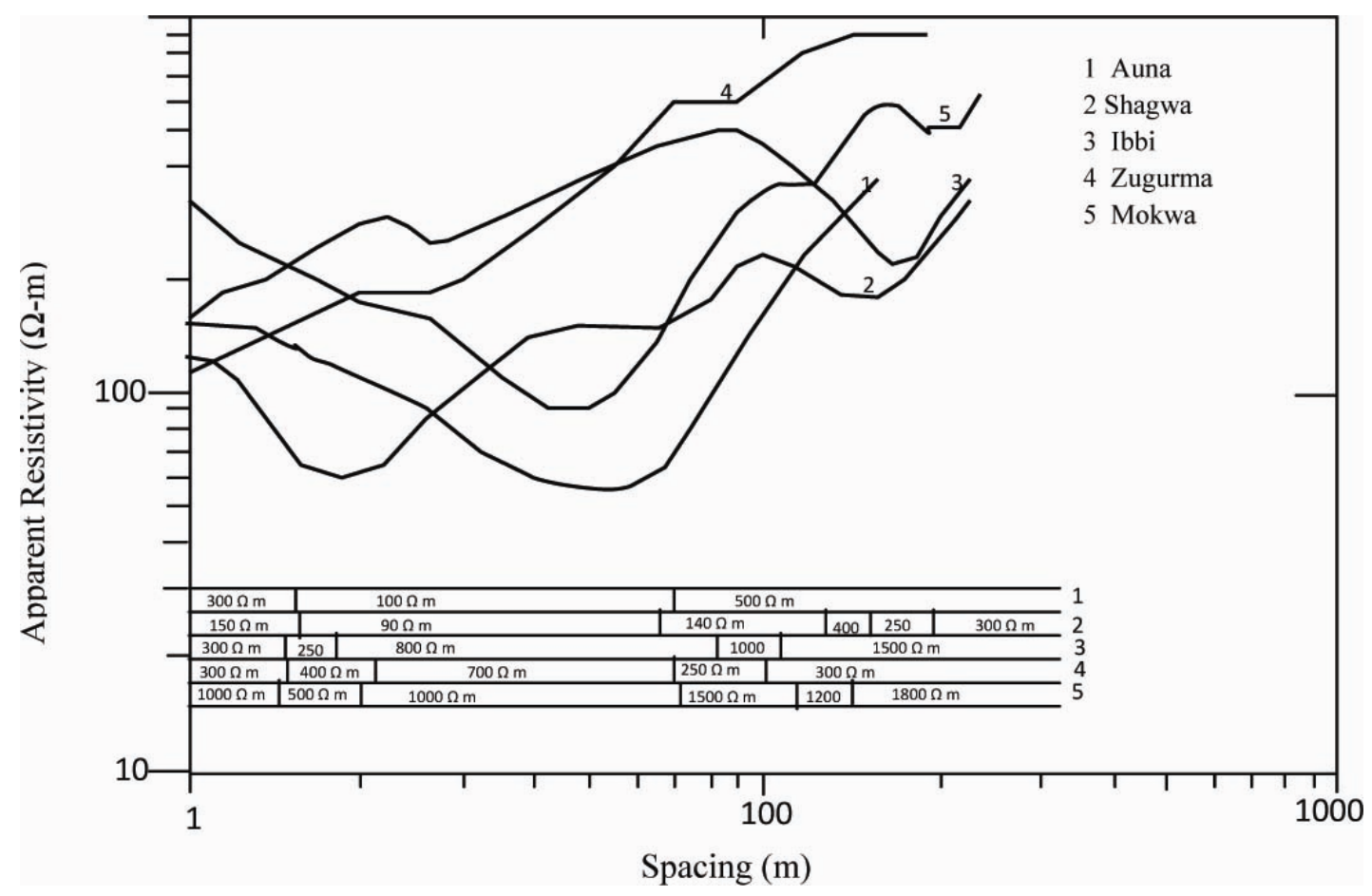

Figure 5a. Typical resistivity type curve and interpretation for profile 1 (NW-SE)

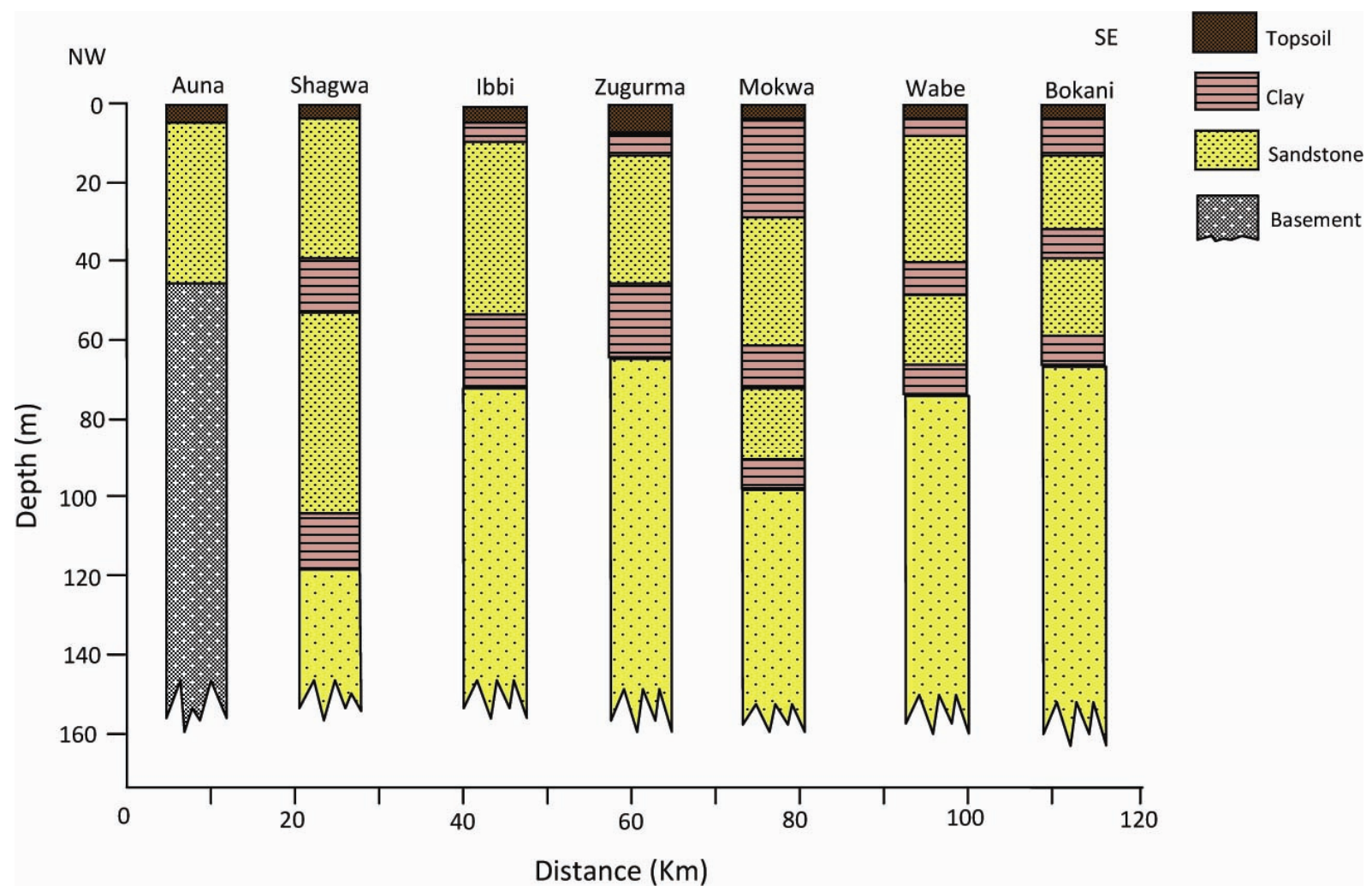

Figure 5b. Geoelectric logs of profile 1 (Auna to Bokani) in the NW-SE direction 


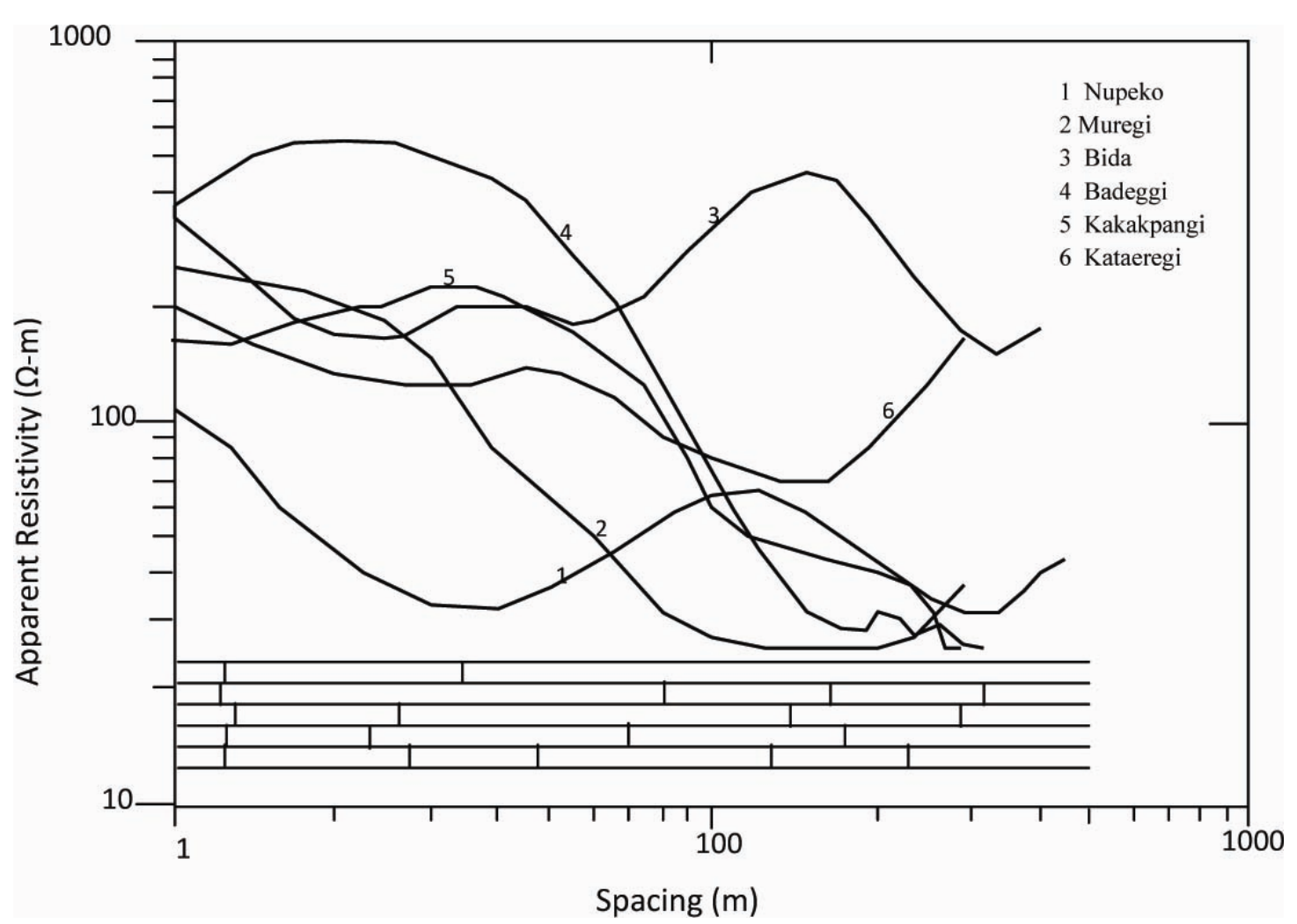

Figure 6a. Typical resistivity curves for profile 5 (Nupeko to Kataeregi) in the NE-SW direction

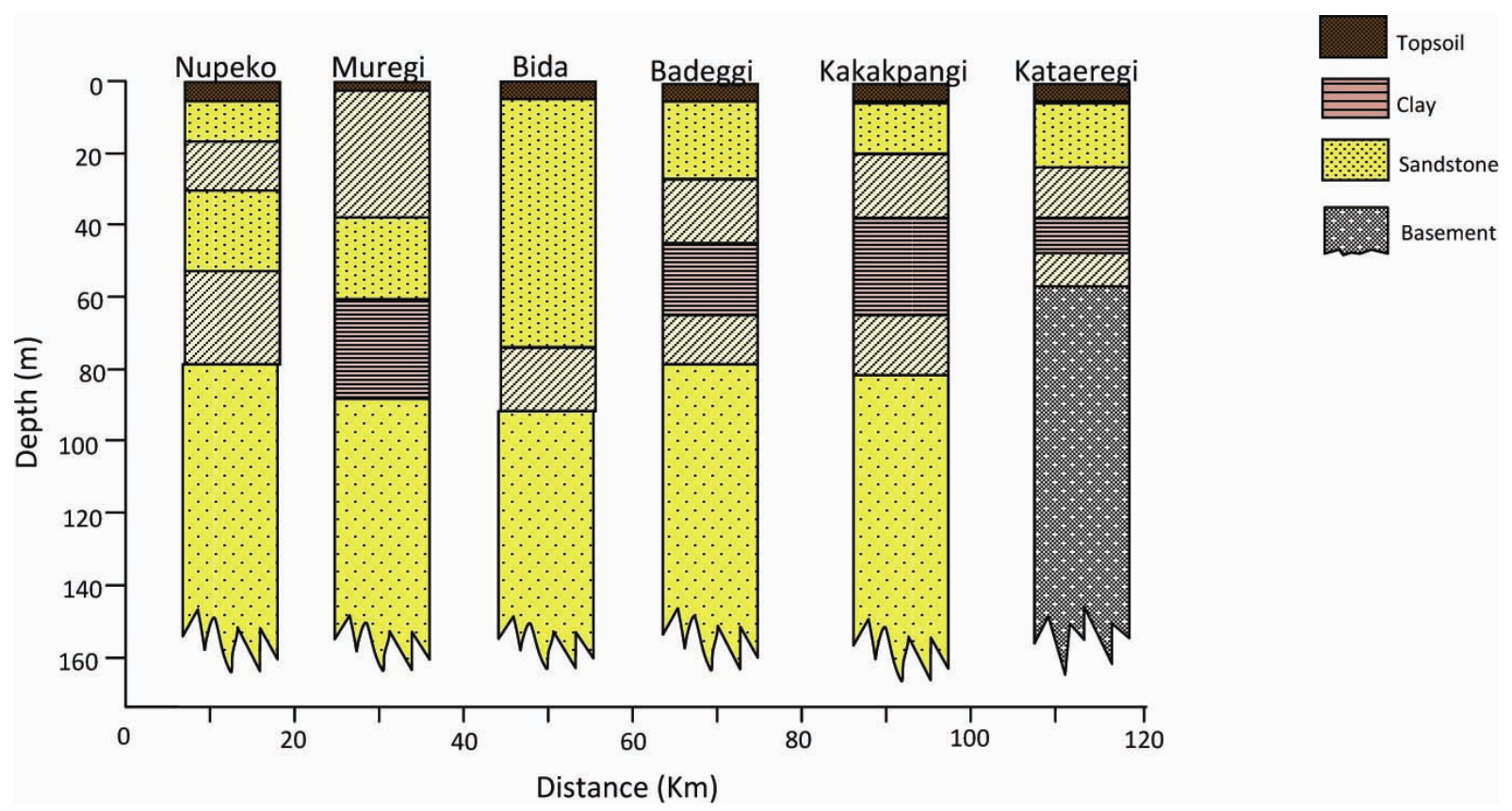

Figure 6b. Geoelectric logs for profile 5 (Nupeko to Kataeregi) in the NW-SE direction 

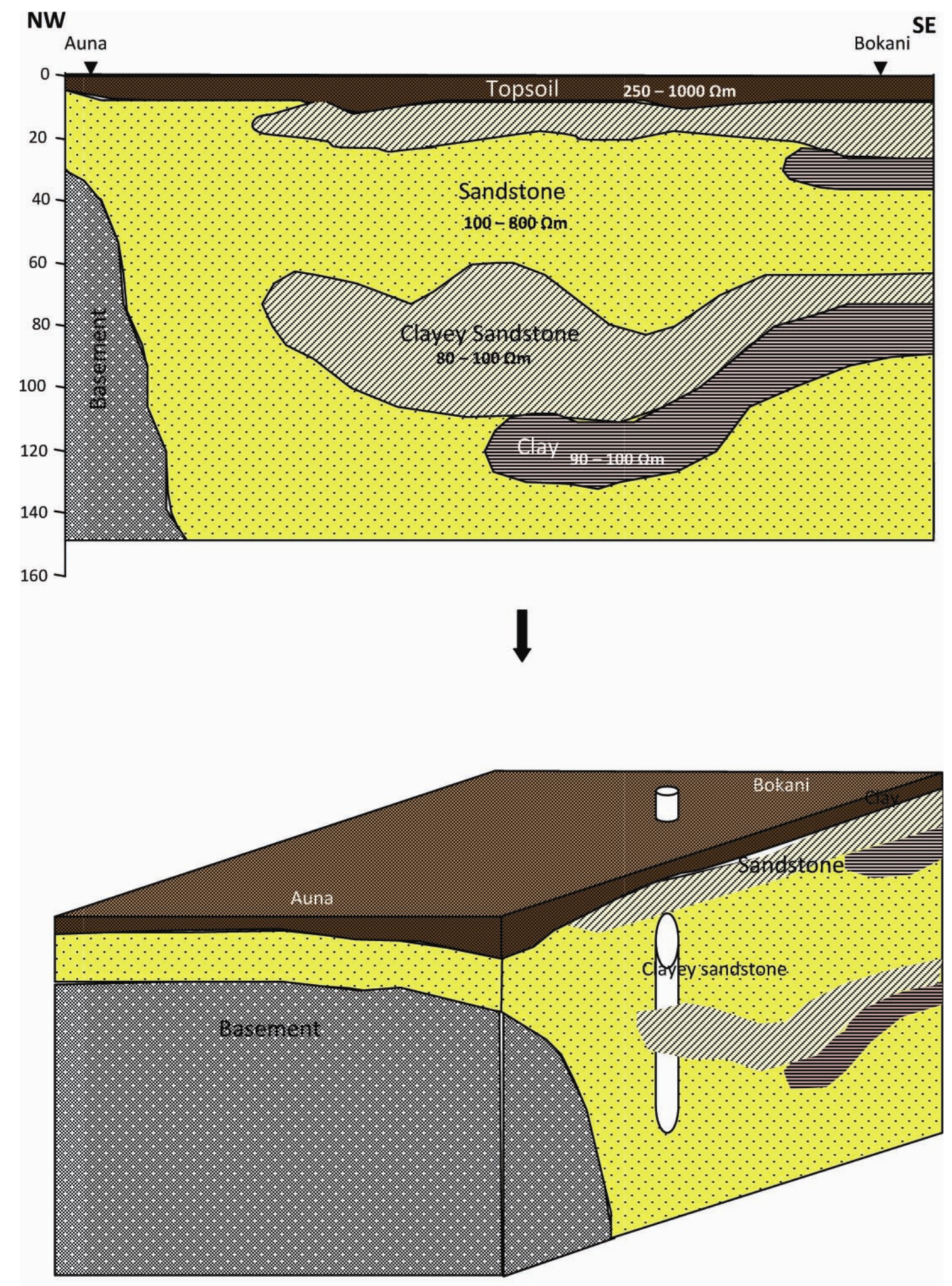

Figure 7. Geoelectric section for section 1 (Auna to Bokani) 

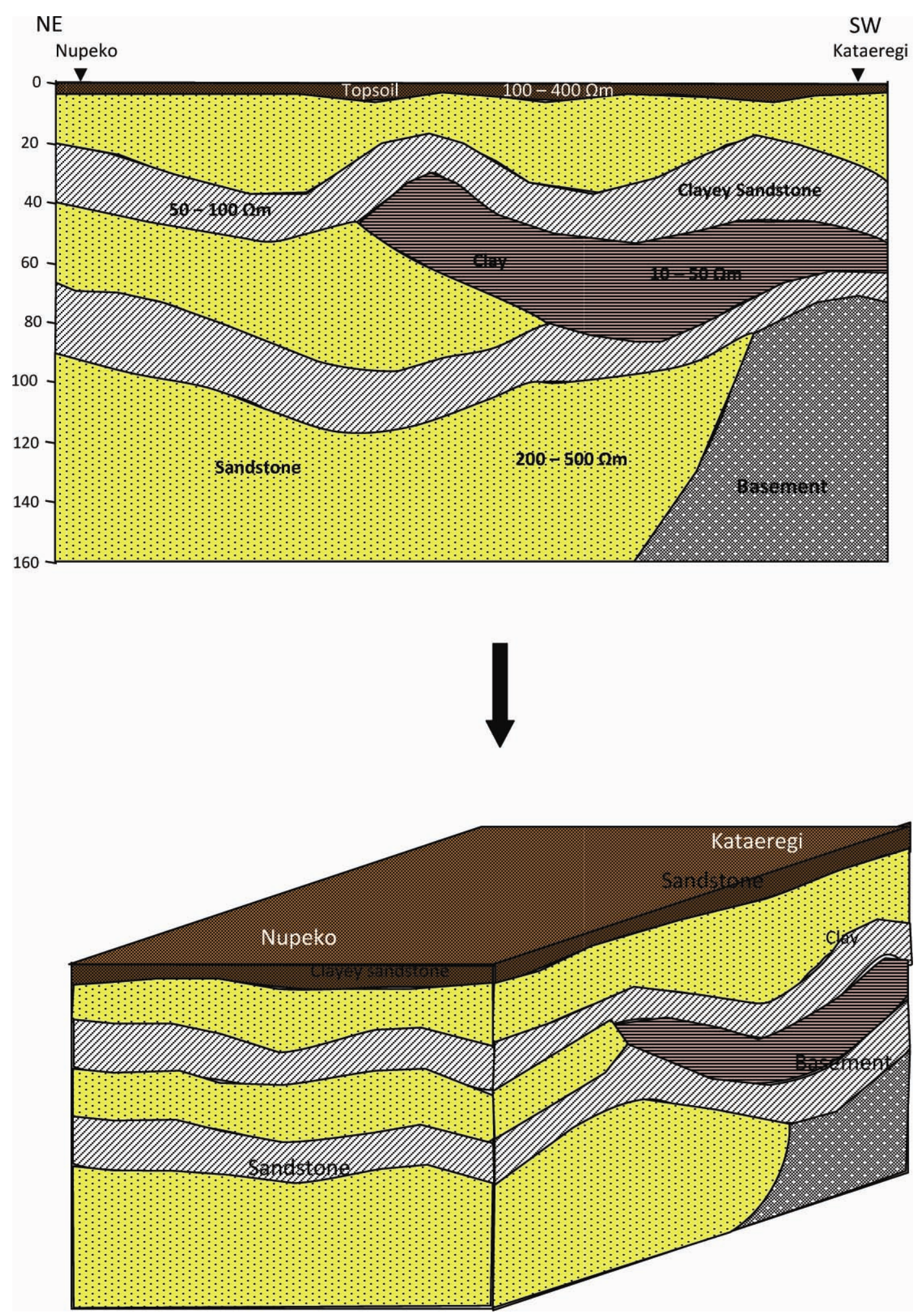

Figure 8. Geoelectric section for section 5 (Nupeko to Kataeregi)

\section{Discussion of Results}

The different type curves observed in the area and the various sectors they represent are shown in Table 3 , based on distinctive geoelectrical characteristics the type curves have been classified into four groups, with each group representing a different geologic environment. Table 4 shows the frequency of resistivity type curves and the associated geology, while Figure 9 is the percentage frequency curve for the various curve types in the Basin. 
Table 3. Representative curve types for the various sectors in the Basin

\begin{tabular}{lll}
\hline GROUP & CURVE TYPES & GEOLOGIC SECTOR \\
\hline 1 & H, HK & Geologic contact areas / fringes of the Basin \\
2 & A, AA, KHK & Northern Sector \\
3 & HK, HKQ, KHKQ, KHKHK, QQH & Central Sector \\
4 & QHK, KQQ, KQ, QHK, and Q & Southern Sector \\
\hline
\end{tabular}

Table 4. Frequency of resistivity type curves and their geologic environment

\begin{tabular}{|c|c|c|c|}
\hline $\begin{array}{l}\text { Curve } \\
\text { Type }\end{array}$ & Frequency & $\begin{array}{l}\text { Percentage } \\
\text { Occurrence }\end{array}$ & Geologic Environment \\
\hline $\mathrm{H}$ & 10 & 7 & Fringes of the Basin (contact areas with the Basement Complex) \\
\hline $\mathrm{K}$ & 2 & 1.5 & Southern Sector, mostly Clay /Shale \\
\hline Q & 4 & 2.8 & Southern / Central sector, alternation of sandstone and clay \\
\hline A & 6 & 4.3 & Northern sector, mostly sandstone with some clay \\
\hline AA & 34 & 24 & Northern sector, mostly sandstone with little or no clay \\
\hline HK & 6 & 4.3 & $\begin{array}{l}\text { Central / Southern sector, clayey surface, alternation of } \\
\text { sandstone and clay at depth. }\end{array}$ \\
\hline HKQ & 10 & 7 & Central sector, clayey up to $30 / 50 \mathrm{~m}$ then sandstone at depth. \\
\hline KHK & 2 & 1.4 & Central to southern sector, alternation of sandstone and clay. \\
\hline QQH & 26 & 18 & Southern to Central sector, mostly clay / shale and sandstone. \\
\hline QHK & 4 & 2.8 & Southern sector, mostly sandstone and shale. \\
\hline KQ & 18 & 13 & $\begin{array}{l}\text { Southern / Northern sector, lateritic/ironstone top, alternation of } \\
\text { sandstone and clay at depth. }\end{array}$ \\
\hline KQQ & 4 & 2.8 & Northern / Central sector, alternation of sandstone and clay. \\
\hline KHKQ & 8 & 6 & $\begin{array}{l}\text { Central to Southern sector, alternation of sandstone and } \\
\text { clay/clay. }\end{array}$ \\
\hline KHKHK & 6 & 4.3 & Central sector, ferruginised sandstone and sandstone. \\
\hline TOTAL & 140 & 100 & \\
\hline
\end{tabular}

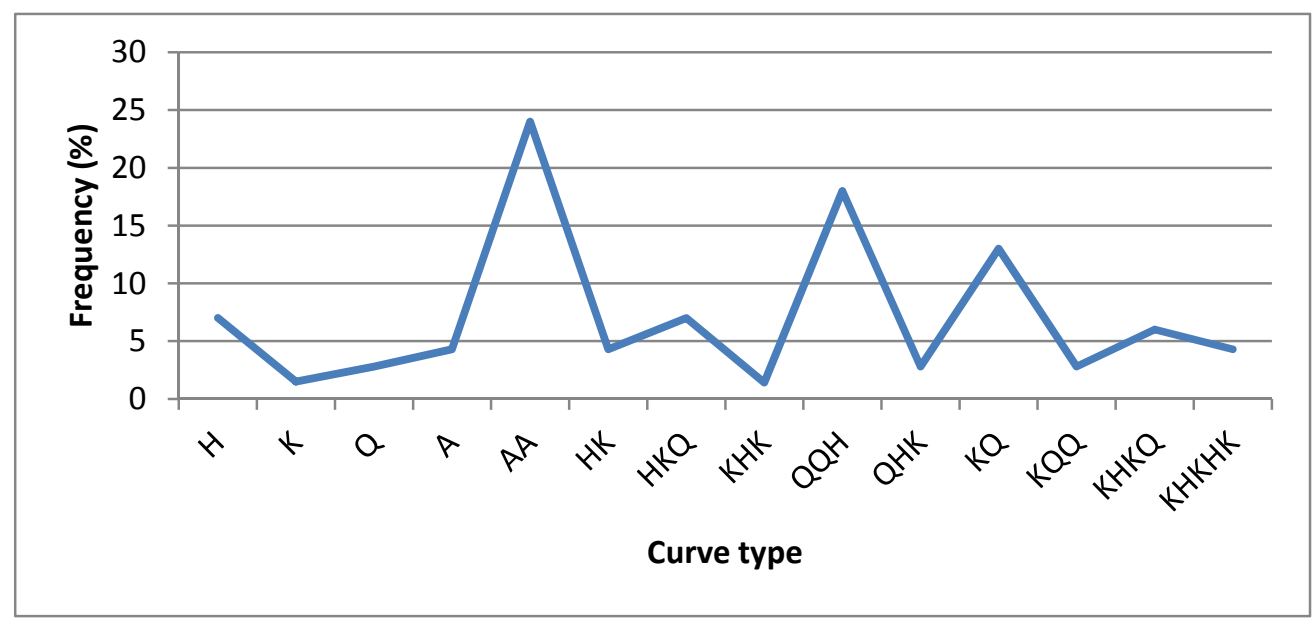

Figure 9. Percentage frequency curve for the various curve types in the Basin 


\subsection{Group $1(H, H K)$}

These are typical curve types obtainable from the basement complex and geological contact areas. $\mathrm{H}$ curves are obtained where the basement is considerably shallow, typically less than $12 \mathrm{~m}$. It consists of the topsoil, weathered basement and the underlying bedrock. HK curve types are obtained where the basement is considerably deeper, mostly greater than $30 \mathrm{~m}$. The geology is represented by distinguishable beds of sandstone / clay, weathered basement (fairly to deeply weathered) and the underlying bedrock. Geophysical surveys have enabled a determination of the basement structures in the fringes of the basin. Significant differences occur over short distances in the basin ranging from $12 \mathrm{~m}$ to over $60 \mathrm{~m}$ depth to basement within a span of just $1 \mathrm{~km}$. This is the least of the four groups.

\subsection{Group 2 (A, AA, KHK)}

These are mostly obtained in the Northern sector of the basin. The A type typifies a geological sequence of mainly ferruginised sandstone at a shallow depth, clayey sandstone and sandstone that is fairly loose to compact. Type AA shows a rapidly alternating sequence of thick layers of loose sandstone and slightly clayey sandstone. This sequence is seen to continue until it changes into the KHK type which shows a highly compact and ferruginised sandstone at a shallow depth of less than $20 \mathrm{~m}$, then clayey sandstone with a low resistivity loose to fairly compact sandstone at depth. These curve types characterize a very large area, extending from the Northern part of Kutigi to Mokwa, Makera, Mashegu Kaboji and Kontagora. It indicates a clearly distinct geology from the other parts of the Basin. Greatest percentage of curves falls within this group.

\subsection{Group 3 (HK, $H K Q, K H K Q$, KHKHK, $Q Q H)$}

These curve types mostly occur in the Central sector of the Basin. The HK, KHK and KHKHK types are obtainable from around the contact areas as well as the areas where the sector grades into the Northern sector. The geology is mainly an alternating sequence of sandstone, clayey sandstone and clay. The sandstone is ferruginised in some places and is also fairly compact. The HKQ, KHKQ and QQH represent areas with thick layers of clay overlying the mostly compact sandstone. They are found mostly in the middle to southern part of the central sector where it grades into the southern sector. It extends from the southern part of Kutigi through Bida, Agaie, Lapai, Duma to Badeggi, Gbako, Lemu, down to Wushishi where it contacts the Basement Complex rocks. The sector shares the characteristics of both the Northern and Southern sectors. This is the second largest percentage among the four groups.

\subsection{Group 4 ( $Q H K, K Q Q, K Q, Q H K, Q$ )}

These typically occur in the Southern sector of the basin. The geology is mainly compact sandstone, clay/shale and ferruginised sandstone. Where ferruginised sandstone / laterite occur at shallow depth, the QHK curve is obtained, indicating a sequence of clay, laterite, sandstone and clay/shale. KQQ also indicates laterite at shallow depths underlying which is the clay/shale with a marked absence of sandstone. The alternation of sandstone and clay that was noticed in the Northern and Central sectors is missing in this sector, instead thick layers of clay/shale predominates. This is the third in percentages among the four groups.

The Northern sector has a characteristic A type curve, while the Southern sector has the Q type. The central sector occupies an intermediate position between the two and the geological contact areas have the $\mathrm{H}$ type as the characteristic curve type.

The interpreted VES data have been used to draw the geo-electrical sections along the nine profiles. These are shown in Figures 7 and 8 . The thicknesses and the resistivities of the various geo-electric layers have been indicated. These are considered essential in characterization of the various aquifers in the area. The characteristics of the various geo-electric layers are shown in Table 5. Six geo-electric layer types have been recognized;

Table 5. Summary of Layer resistivity

\begin{tabular}{ll}
\hline 1 & Topsoil characterised by resistivity of 50 to 500 Ohms-meter \\
2 & Laterite/ Ferruginised Sandstone characterised by resistivity of 800 to $2000 \mathrm{Ohm}$-meters \\
3 & Sandy Clay characterised by resistivity of 80 to $200 \mathrm{Ohm}$-meters \\
4 & Clayey Sandstone characterised by resistivity of 150 to $500 \mathrm{Ohm}-$ meters \\
5 & Sandstone characterised by resistivity of 300 to $1500 \mathrm{Ohm}$-meters \\
6 & Clay / Shale characterised by resistivity of 10 to $100 \mathrm{Ohm}$-meters \\
\hline
\end{tabular}




\section{Conclusion}

Geo-electrical properties of the basin indicate that three major curve types predominate; these are the AA, QQH and KQ types. These curve types are diagnostic of the three sectors the basin was divided into in this study, the Northern sector has type AA, the central sector has QQH while the southern sector is characterized by the KQ type. The $\mathrm{H}$ - type indicate mostly contact areas with a shallow pile of sedimentary deposits. These are found mostly along the fringes of the Basin.

The Geoelectric section for profile 1 show a sedimentary pile of 2 to $30 \mathrm{~m}$ at the fringe of the basin and a steep drop of the basement structure to over $140 \mathrm{~m}$ over a short distant $(<1 \mathrm{~km})$. It can be deduced from this that the basin may have resulted from faulting that led to a down thrust of the middle portion, which eventually became infilled with sediments. The aquifer is mostly in the unconfined state. Profile 4 extends from Nupeko, which occurs at the extreme southern end of the study area where River Kaduna joins River Niger, to Kudu shows an aquifer that is mostly in a semi-confined state with perched aquifer conditions around Nupeko, Kusoko and Kutigi, ferrugious laterite/ironstone which forms the cap of the Basin occurs mostly around Kudu. It can be deduced from this that the environment of deposition of the sediments from profiles 1 to 4 is a high energy environment, judging from the relative absence of fines (clay and silts) with the sands predominating. Profile 5, which extends from Nupeko to Kataeregi shows an aquifer that is also mostly in an unconfined to semi-confined condition, it is also perched around Kataeregi area. Ketaeregi represents the Eastern contact of the Basin with the Basement complex rocks, the town is about $45 \mathrm{~km}$ from Minna, the capital of Niger State. The sedimentary pile ranges from a thickness of $20 \mathrm{~m}$ to over $100 \mathrm{~m}$ within a span of $1 \mathrm{~km}$. The environment of deposition is mostly low to high energy.

Profile 6 extends from Bida to Akerre and shows an aquifer that is mostly in the semi-confined to confined state with the confining layer being mostly clay the upper confining layer occurs at a depth of about $40-60 \mathrm{~m}$ with a thickness of about 20-30 m, while the lower confining unit occurs at a depth of about 90-120 m with a thickness of about 10-20 m. In between the two units is the first confined aquifer with a thickness of about $10 \mathrm{~m}$ occurring at a depth of 70-100 m. The lower aquifer contacts the basement in the SE and occurs at a depth of between $100-120 \mathrm{~m}$.

Profile 7 extends from Badeggi to Ebbo and occurs from the central to southern parts of the Basin in the NE-SW direction. The geology consists mostly of perched and confined aquifers. The confining unit is mostly clays and shale. The clayey sandstone are aquitards that transmits water to wells placed in them in small quantities to be almost negligible, deep hand dug wells in the area tap their water from this unit. The aquifer, which is basically sandstone, occurs at below $100 \mathrm{~m}$ with an undetermined thickness. The sandstone has a low resistivity of between 100 to $250 \Omega \mathrm{m}$, while the clay/shale has a resistivity of between $10-50 \Omega \mathrm{m}$.

Profile 8 extends from Lapai to Ebbo and shows a transition from the central to the Southern sector of the basement. The Basement structure in Lapai occurs at between $4 \mathrm{~m}$ to over $100 \mathrm{~m}$ within a span of $1 \mathrm{~km}$ (Local Government Secretariat and Emirs palace respectively). The aquifer is in the semi-confined to confined state. The area is charaterised by a layer of ferruginised sandstone with a high resistivity of $>1000 \Omega \mathrm{m}$ and thickness of between 5 to $10 \mathrm{~m}$. Two units of aquifers occur in the area at $90 \mathrm{~m}$ and $140 \mathrm{~m}$. The two are separated by a clay/shale unit with a thickness of between 10-20 m. The clayey sandstone is also an aquitard that yields very low quantity of water to wells placed in them.

Profile 9 extends from Ndaloke to Muye, this profile is also typical of the southern sector where clays/shale predominates over the sandstone. The aquifer in this area is also perched to confined, the gravelly sandstone occurs as a perched aquifer resting on the clayey sandstone, it has thickness of about 10-20 m and occurs at between 3-6 m depth. The shale/clay unit occurs at between 30-60 $\mathrm{m}$ at Ndaloke and generally at below $100 \mathrm{~m}$.

It becomes quite evident that three major sectors occur in the basin, the Northern sector with mostly unconfined aquifers, the extensive central sector with semi-confined to confined aquifers and the southern sector with perched to semi-confined and confined aquifers.

The environment of deposition indicates a high energy environment in the northern sector with a marked reduction in deposition energy towards the southern sector of the basin in the NW-SE direction.

\section{References}

Adeleye, D. R. (1974). Sedimentology of the fluvial Bida Sandstones (Cretaceous), Nigeria. Sediment Geology, 12, 1-24. http://dx.doi.org/10.1016/0037-0738(74)90013-X 
Adeleye, D. R., \& Dessauvagie, T. F. J. (1972). Stratigraphy of the Mid-Niger Emabyment near Bida, Nigeria. In T. J. F. Dessauvagie, \& A. J. Whiteman (Eds.), Proceedings of the Conference on African Geology (pp. 181-186). Ibadan: Ibadan University Press.

Adeniyi, J. O. (1985). Ground total magnetic intensity in parts of the Nupe Basin and the adjacent basement complex, Niger State, Nigeria. Nigerian Journal of Applied Sciences, 3, 67-78.

Dessauvagie, T. F. J. (1975). Geological map of Nigeria, 1:1,000,000 with explanatory notes. Journal of Mining Geology, 9, 1-12.

Falconer, J. D. (1911). The geology and geography of Northern Nigeria (p. 135). London: Macmillan.

Kogbe, C. A., Ajakaiye, D. E., \& Matheis, G. (1983). Confirmation of rift structure along the Mid-Niger Valley, Nigeria. Journal of African Earth Science, 1, 127-131.

Obaje, N. G. (2009). Geology and Mineral Resources of Nigeria. Lecture Notes in Earth Sciences, 120.

Ojo, S. B. (1984). Middle Niger Basin revisited: magnetic constraints on gravity interpretations. Abstract, 20th Conference of the Nigeria Mining and Geosciences Society, Nsukka, pp. 52-53.

Ojo, S. B., \& Ajakaiye, D. E. (1989). Preliminary interpretation of gravity measurements in the Mid-Niger Basin area, Nigeria. In C. A. Kogbe (Ed.), Geology of Nigeria (2nd ed., pp. 347-358). Lagos: Elizabethan Publishers.

Udensi, E. E., \& Osazuwa, I. B. (2004). Spectral determination of depths to magnetic rocks under the Nupe Basin, Nigeria. NAPE Bull., 17, 22-27.

Whiteman, A. (1982). Nigeria: its petroleum geology, resources and potential (p. 381). London: Graham and Trotman. http://dx.doi.org/10.1007/978-94-009-7361-9 